\title{
ORIGINAL ARTICLE \\ PEMILIHAN ANALGESIK EKSTERNAL UNTUK MENGATASI NYERI OTOT PADA KULI ANGKUT PUSAT GROSIR SURABAYA
}

Nida Septioning Sukma, Devy Maulidya Cahyani, Yuniar Tri Saskia Revi, Evelyn Clarissa Febiany, Fatihatul Alifiyah, Berlian Sarasitha Hariawan, Iffah Khosyyatillah, Ni'matul Khoiriyyah, Savira Putri Ayuningtyas, Firda Rosyidah, Mufarrihah

Departemen Farmasi Komunitas, Fakultas Farmasi, Universitas Airlangga Gedung Nanizar Zaman Joenoes Kampus C, Jl. Ir. Soekarno, Surabaya 60115, Indonesia

E-mail: mufarrihah@ff.unair.ac.id

\begin{abstract}
ABSTRAK
Di Indonesia rata-rata buruh mengalami nyeri otot dan menggunakan analgesik eksternal untuk menangani nyeri otot. Tujuan dari penelitian ini adalah mengetahui bagaimana penanganan nyeri otot dan apa saja yang memengaruhi pemilihan analgesik eksternal oleh kuli angkut di Pusat Grosir Surabaya (PGS), pengetahuan tentang analgesik eksternal serta peran apoteker dalam pelaksanaan swamedikasi terkait pemilihan analgesik eksternal. Rancangan penelitian yang digunakan adalah cross-sectional. Sampel pada penelitian ini adalah kuli angkut PGS. Data disajikan secara deskriptif dalam bentuk grafik dan tabel berdasarkan jawaban responden pada kuesioner. Total responden berjumlah 100 orang. Mayoritas responden pernah merasakan nyeri di bahu kanan (36) 9,8\%. Waktu terjadinya nyeri adalah setelah melakukan aktivitas (84) 82,3\% dengan intensitas nyeri sedang (55) 55\% dan usaha untuk mengatasi nyeri paling banyak menggunakan obat luar (72) $41,1 \%$ jenis obat oles (63) $51,2 \%$ dengan efek panas yang diharapkan (80) $74,8 \%$. Alasan dari pemilihan analgesik eksternal adalah khasiat yang ditimbulkan (76) 60,3\%. Peran apoteker dalam edukasi analgesik ekstenal masih minim dilihat dari (44) $44 \%$ responden memiliki pengetahuan yang kurang mengenai nyeri dan penggunaan analgesik eksternal. Responden banyak memperoleh obat dari toko atau warung (57) $51,8 \%$, apabila nyeri berlanjut kebanyakan responden memilih untuk pergi ke dokter (43) $38,7 \%$.
\end{abstract}

Kata Kunci: Nyeri otot, analgesik eksternal, swamedikasi, pengetahuan, survei

\begin{abstract}
Most porters in Indonesia, had experience in muscle pain and used external analgesics to manage the pain. This research aimed to identify how porters in Pusat Grosir Surabaya (PGS) deal with muscle pain, what factors affecting the choices of external analgesics, their knowledge of external analgesics and pharmacists' role in self-medication related to the choices of external analgesics. The study was designed as a cross-sectional in which data were collected using a self-administered questionnaire in porters at PGS. About 100 porters agreed to participate in the study. Most of the participants (9.8\%) felt muscle pain in the right shoulder. Participants $(n=84)$ experienced musle pain mostly with moderate intensity (55\%) and treated with external analgesics (41.1\%). Most porters (51.2\%) used ointment external analgesic in which $74.8 \%$ of them used it to get the warm effect. The eefficacy $(60.3 \%)$ was the main reason for them in choosing external analgesics. This study also showed that the pharmacists' role in educating external analgesics usage is needed, as the data shows that about $44 \%$ respondents hadless knowledge about muscle pain and external analgesics used. The majority of respondents (51.8\%) bought external analgesics from conventional store andif the muscle pain continueed, most of them (38.7\%.) chose to go to the doctor.
\end{abstract}

Keyword: Muscle pain, external analgesics, self-medication, knowledge, survey 


\section{PENDAHULUAN}

Nyeri adalah pengalaman sensorik yang tidak menyenangkan akibat kerusakan jaringan, baik aktual maupun potensial atau yang digambarkan dalam bentuk kerusakan tersebut (Bahrudin, 2018). Jika terjadi pada otot, nyeri akan menimbulkan keluhan berupa rasa sakit, berat, kaku, atau kram. Penyebab terjadinya nyeri otot dipicu karena penggunaan otot yang salah atau berlebihan sehingga otot akan mengalami defisiensi oksigen dan terjadi oksidasi anaerob yang akan menghasilkan produk berupa asam laktat. Asam laktat inilah yang menimbulkan rasa nyeri. Sebab lain yang menimbulkan rasa nyeri ialah defisiensi vitamin B12, D, dan pengonsumsian obat-obatan yang menginduksi nyeri seperti golongan statin (penurun kolesterol), dan bisa juga disebabkan oleh autoimun (Maskur, Della, \& Handini, 2013)

Pekerjaan yang mengandalkan aktivitas fisik berlebih, seperti yang dilakukan buruh pabrik, merupakan salah satu faktor yang menimbulkan nyeri otot. Berdasarkan Penelitian yang dilakukan Tanderi, $50-80 \%$ pekerja di seluruh dunia pernah mengalami nyeri punggung bawah (Tanderi, 2017). Penelitian lain menyebutkan 6-76\% pekerja menderita nyeri di daerah leher (Ariens et al, 2001). Survei oleh Balai Kesehatan Tenaga Kerja Bogor di pabrik pewarnaan benang PT. X menunjukkan bahwa pekerja yang mengalami keluhan nyeri otot pada area bahu sebanyak $47,4 \%$, siku $12,3 \%$, paha atas $7,2 \%$, lutut $9,3 \%$, kaki $11,3 \%$, tungkai bawah $42,3 \%$, punggung bawah $65,9 \%$ dan area leher-punggung atas 20,6\% (Balai Kesehatan Tenaga Kerja Bogor, 2004). Nyeri pada pekerja diduga kuat terkait dengan aktivitas fisik yang dilakukan dalam waktu lama. Pekerja fisik dengan jam kerja melebihi 41jam/minggu cenderung mengalami nyeri (Lee, 2018). Di Indonesia, jumlah jam kerja untuk buruh, karyawan dan pegawai adalah 45 jam/minggu dengan jumlah buruh, karyawan dan pegawai 34.870.462 orang. Angka ini terus meningkat dari tahun 2016 (BPS, 2019)

Berdasarkan data laporan Komisi Pengawas Eropa kasus nyeri otot mengakibatkan sebanyak 49,9\% ketidakhadiran dalam bekerja lebih dari tiga hari dan $60 \%$ kasus ketidakmampuan permanen dalam bekerja. Hasil penelitian yang telah dilakukan di Argentina pada tahun 2010 menunjukkan bahwa dari 22.013 kasus penyakit akibat kerja, diantaranya nyeri otot merupakan kejadian yang paling sering terjadi. Sedangkan di Korea kasus nyeri otot mengalami peningkatan yang sangat tinggi dari 1.634 pada tahun 2001 menjadi 5.502 pada tahun 2010 (Sang et al. 2014).

Rasa nyeri pada otot dapat diatasi dengan penggunaan produk eksternal analgesik. Pada umumnya, analgesik eksternal ada dua jenis, yaitu NSAID topikal dan counterirritant. NSAID topikal direkomendasikan karena dianggap bahwa obat tersebut langsung bekerja pada bagian yang terkena dampak (nyeri), sehingga akan menghindari efek samping pada sistemik dan efek samping yang dihasilkan dari pemberian oral. NSAID topikal yang sering digunakan meliputi ibuprofen, diklofenak, felbinak, dan ketoprofen. Counterirritant memiliki mekanisme kerja sebagai analgesik eksternal dengan menghasilkan vasodilatasi lokal, memberikan sensasi hangat pada kulit. Counterirritant yang sering digunakan meliputi mentol, metil salisilat, kamper, dan capsicum (Nathan, 2008).

Analgesik topikal yang banyak beredar di pasaran seperti natrium diklofenak, metil salisilat, kamfer dan lainnya merupakan produk over the counter yang penggunaannya relatif mudah, karena alasan ini masyarakat lebih memilih untuk melakukan swamedikasi. Namun, sebuah penelitian menunjukkan penggunaan obat analgesik untuk swamedikasi nyeri oleh masyarakat Kabupaten Demak menyatakan 31\% (46 dari 147 responden) menggunakan analgesik secara swamedikasi tidak rasional terkait ketepatan golongan, obat, dosis, dan waktu penggunaan (Afif, 2015).

Swamedikasi atau self-medication berpotensi menimbulkan risiko bagi individu atau konsumen yang melakukannya, yaitu kesimpulan diagnosis diri sendiri yang kurang tepat, gagal untuk menanyakan saran medis yang sesuai dengan segera, pilihan terapi yang tidak akurat, gagal mengenali resiko farmakologis yang tidak biasa, terjadi efek samping obat yang tidak biasa namun parah, tidak mengetahui adanya kontraindikasi, interaksi, peringatan, dan tindakan pencegahan yang dibutuhkan, gagal membedakan bahwa bahan aktif yang sama telah digunakan dengan nama yang berbeda, gagal melaporkan self-medication yang baru dilakukan ke dokter yang meresepkan (pengobatan ganda/interaksi berbahaya), gagal mengenali atau melaporkan reaksi obat yang merugikan, rute penggunaan yang salah, dosis berlebihan, penggunaan terlalu lama, risiko ketergantungan dan penyalahgunaan, interaksi makanan dan obat-obatan, serta penyimpanan dalam kondisi yang salah atau melampaui waktu penyimpanan yang disarankan. Selain itu, swamedikasi yang salah juga berdampak pada tingkat komunitas, yaitu mengakibatkan peningkatan penyakit akibat obat, 
toleransi, resistensi dalam tubuh, dan pemborosan pengeluaran publik (WHO, 2000).

Terdapat banyak kasus swamedikasi nyeri menggunakan analgesik eksternal, namun jumlah penelitian mengenai swamedikasi analgesik eksternal untuk nyeri masih sedikit. Di dalam penelitian ini diteliti bagaimana penanganan nyeri otot dan apa saja yang mempengaruhi pemilihan analgesik eksternal oleh kuli angkut di Pusat Grosir Surabaya (PGS), pengetahuan tentang analgesik eksternal serta peran apoteker dalam pelaksanaan swamedikasi terkait pemilihan analgesik eksternal.

\section{METODE PENELITIAN}

Metode penelitian yang digunakan dalam penelitian ini adalah deskriptif dengan desain cross-sectional dan teknik pengambilan sampel purposive sampling. Cara pengambilan data menggunakan instrumen berupa kuesioner. Kuesioner yang digunakan memiliki model pertanyaan pilihan ganda dengan jawaban tunggal dan lebih dari satu, serta pernyataan benar-salah. Sebelum digunakan, dilakukan uji coba kuesioner pada individu yang memiliki kriteria mirip dengan calon responden.

Populasi penelitian adalah seluruh pekerja jasa angkut pada Pusat Grosir Surabaya (PGS) dengan jumlah sampel yang digunakan ialah 100 pekerja jasa angkut. Sampel penelitian dipilih berdasarkan kriteria inklusi yaitu pekerja jasa angkut, pernah merasakan nyeri, dan pernah menggunakan produk analgesik eksternal. Lokasi ini dipilih sebagai lokasi penelitian berdasarkan pada banyaknya pekerja jasa angkut. Waktu pengambilan data dilakukan pada tanggal 12 September 2019. Data dari hasil penelitian disajikan secara deskriptif. Data ditunjukkan dalam bentuk grafik dan tabel frekuensi dari hasil jawaban responden pada kuesioner.

\section{HASIL DAN PEMBAHASAN}

\section{Karakteristik Responden}

Jumlah responden 100 orang dengan karakteristik pada Tabel 1. Jumlah responden mayoritas berjenis kelamin laki-laki 98 (98\%). Hal ini menunjukkan bahwa target penelitian yang berprofesi sebagai jasa angkut pada Pusat Grosir Surabaya (PGS) didominasi oleh para pekerja laki-laki. Menurut Laporan Ketenagakerjaan Indonesia tahun 2017 oleh ILO, dilaporkan bahwa presentase para pekerja kasar seperti jasa angkut barang mayoritas ialah laki - laki dengan presentase $35,5 \%$ sedangkan pekerja kasar dengan jenis kelamin perempuan hanya sekitar $19 \%$. Berdasarkan Tabel 1. di mana responden dikelompokkan sesuai usia maka paling banyak pekerja pada usia 20-29 tahun yaitu sejumlah 42 responden.

Undang-undang No 13 tahun 2003 tentang ketenagakerjaan menyebutkan bahwa usia kerja ialah orang dengan usia 18-64 tahun sehingga dapat disimpulkan bahwa mayoritas pekerja kuli angkut pada Pusat Grosir Surabaya (PGS) termasuk dalam usia produktif untuk bekerja. Namun ada beberapa pekerja yang mulai berkerja sebagai kuli angkut semenjak berusia di bawah usia produktif untuk bekerja. Dari hasil tersebut, diketahui mayoritas responden sebesar $44 \%$ sudah bekerja selama 1-5 tahun.

Tabel 1. Demografi Responden

\begin{tabular}{lc}
\hline Jenis Kelamin & $\mathrm{n}(\%)$ \\
\hline Laki-laki & $98(98 \%)$ \\
\hline Perempuan & $2(2 \%)$ \\
\hline \multicolumn{1}{c}{ Total } & $100(100 \%)$ \\
\hline Usia & $\mathrm{n}(\%)$ \\
\hline$<20$ tahun & $5(5 \%)$ \\
\hline 20-29 tahun & $42(42 \%)$ \\
\hline $30-39$ tahun & $25(25 \%)$ \\
\hline $40-49$ tahun & $17(17 \%)$ \\
\hline $50-59$ tahun & $8(8 \%)$ \\
\hline$\geq 60$ tahun & $3(3 \%)$ \\
\hline \multicolumn{1}{c}{ Total } & $100(100 \%)$ \\
\hline Lama Bekerja & $\mathrm{n}(\%)$ \\
\hline 1-5 tahun & $9(9 \%)$ \\
\hline $6-10$ tahun & $44(44 \%)$ \\
\hline $11-15$ tahun & $18(18 \%)$ \\
\hline $16-20$ tahun & $8(8 \%)$ \\
\hline$>20$ tahun & $8(8 \%)$ \\
\hline \hline
\end{tabular}

\section{Lokasi Nyeri}

Berdasarkan gambar 2, lokasi nyeri yang banyak dialami responden yaitu bahu kanan, bahu kiri, betis kiri, betis kanan, lutut kiri, punggung dan pinggul. Prevalensi lokasi nyeri yang paling tinggi ialah bahu kanan hal ini kemungkinan dikarenakan responden yang berprofesi sebagai kuli angkut lebih sering membawa beban pada bagian bahu kanan sehingga nyeri sering dirasakan pada lokasi tersebut. 


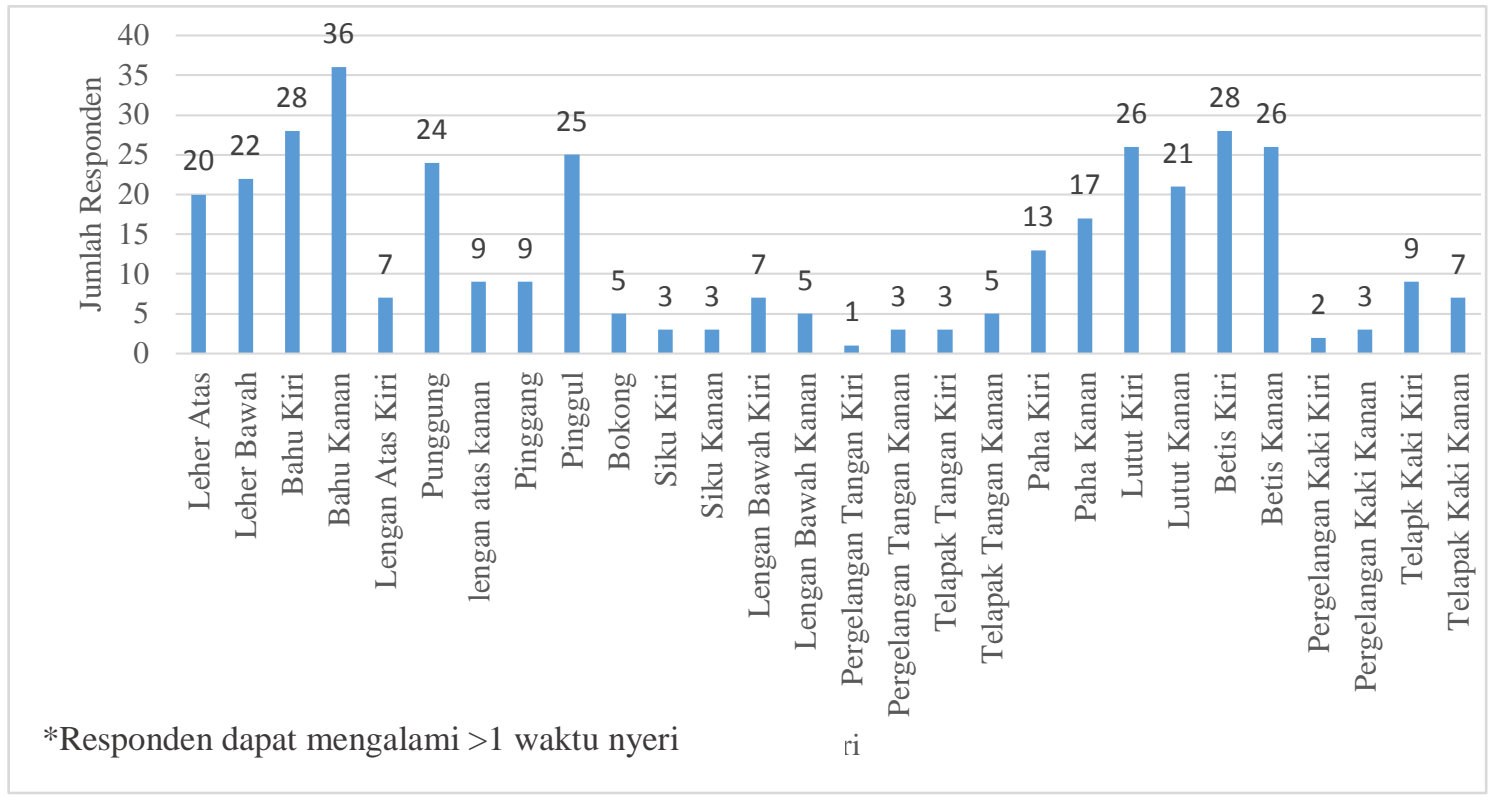

Gambar 2. Persebaran lokasi nyeri yang diderita oleh kuli angkut di PGS

\section{Waktu Terjadinya Nyeri}

Berdasarkan Gambar 1, nyeri paling banyak dialami responden setelah melakukan pekerjaan nyeri tersebut termasuk dalam golongan Delayed-Onset Muscle Soreness (DOMS), yang terjadi setelah melakukan pekerjaan ataupun setelah istirahat (1-2hari). Nyeri DOMS akan membaik seiring waktu walau tanpa pengobatan, sehingga upaya pencegahanlah yang sangat diperlukan.

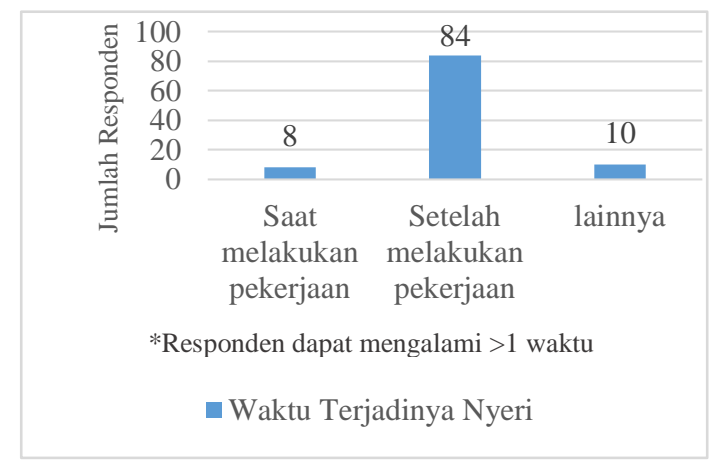

Gambar 1. Waktu timbul rasa nyeri pada kuli angkut di PGS

\section{Derajat Nyeri Otot dan Usaha Untuk Mengatasi Nyeri Otot}

Berdasarkan data derajat nyeri pada Gambar 3 dapat diketahui bahwa mayoritas nyeri yang dialami oleh responden adalah nyeri sedang sebanyak $55 \%$ dan nyeri ringan sebanyak $29 \%$. Usaha untuk mengatasi nyeri dijabarkan pada
Gambar 4, pekerja yang mengalami nyeri dengan derajat ringan kebanyakan mengatasi nyeri dengan beristirahat. Pekerja yang mengalami nyeri derajat sedang, berat, dan tak tertahankan kebanyakan lebih memilih penggunaan obat analgesik eksternal untuk mengatasi nyeri. Pengatasan nyeri bisa dilakukan secara non-farmakologi untuk rasa nyeri ringan dan sedikit efek samping seperti masase, relaksasi dan guide imagery, penggunaan kompres panas dan dingin (Mickey S dan Patricia GB, 2007).

Berdasarkan data lama bekerja pada Tabel 1 dan derajat nyeri yang dirasakan pekerja, diketahui bahwa para pekerja yang bekerja selama kurang dari 1 tahun, rata-rata menderita nyeri berintensitas sedang, pekerja dengan lama kerja 1-5 tahun, rata-rata menderita nyeri berintensitas sedang, sedangkan pada pekerja yang telah bekerja selama 6-10 tahun, rata-rata mengalami nyeri berintensitas berat. Pada para pekerja dengan lama kerja 11 sampai lebih dari 20 tahun menderita nyeri sedang.

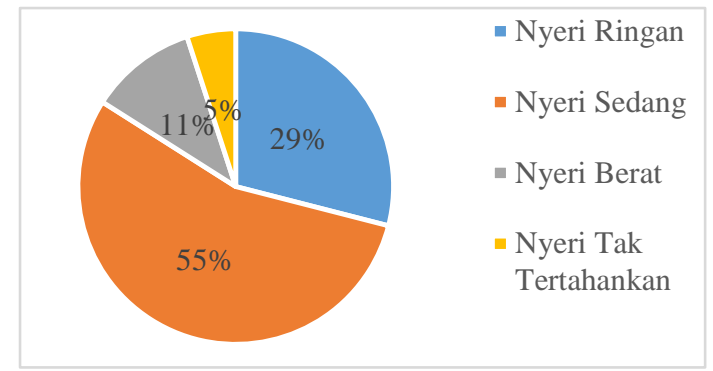

Gambar 3. Derajat nyeri otot kuli Angkut PGS 
Berdasarkan data usia dan derajat nyeri yang dirasakan pekerja jasa angkut, pekerja yang berusia kurang dari 20 tahun hingga usia 29 tahun rata-rata mengalami nyeri sedang. Pada pekerja dengan usia 30-39 tahun, rata-rata menderita nyeri ringan. Pada pekerja usia 40-59 tahun mengalami nyeri ringan sampai sedang. Pada pekerja dengan usia lebih dari 60 tahun mengalami nyeri berat. Mayortas nyeri berat dialami responden dengan usia lebih dari 60 tahun.

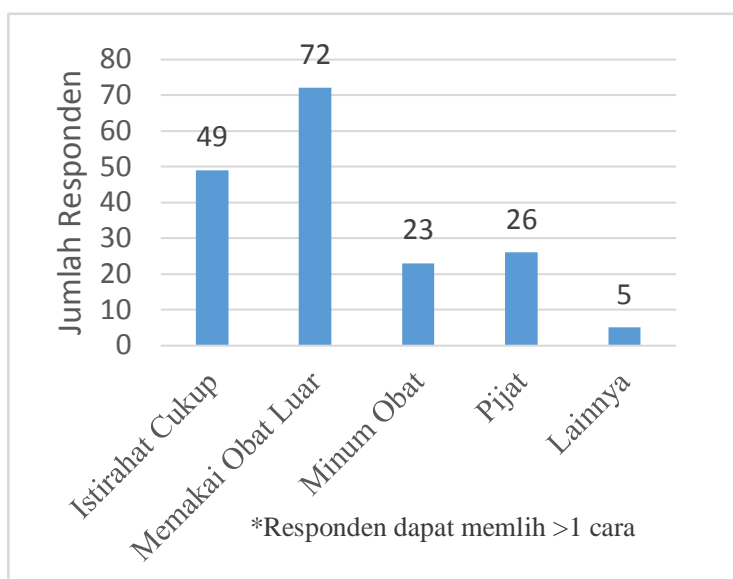

Gambar 4. Usaha untuk mengatasi nyeri yang diderita kuli angkut di PGS

Obat yang Digunakan dan Tempat Membeli Obat

Berdasarkan cara peggunaannya secara umum terdapat beberapa macam obat analgesik eksternal yang digunakan oleh responden yaitu obat oles (gel/krim/salep), obat tempel (koyo/patch), dan minyak gosok.

Berdasarkan data pada Gambar 6 menunjukkan bahwa para pekerja jasa angkut di PGS masih lebih cenderung memilih untuk membeli obat di toko maupun warung dibanding melakukan swamedikasi di apotek yang merupakan tempat untuk mendapatkan obat yang aman dan terjamin. Pemilihan pembelian obat di toko atau warung menunjukkan minimnya atau bahkan tidak adanya peran apoteker dalam pemilihan obat analgesik eksternal. Tidak adanya apotek di sekitar PGS membuat kuli angkut di PGS cenderung membeli obat di toko kelontong terdekat.

Berdasarkan survei yang telah dilakukan, untuk kuli angkut dengan pengetahuan yang kurang dan cukup cenderung memilih membeli obat analgesik eksternal di toko atau warung, sedangkan untuk kuli angkut dengan pengetahuan yang baik selain memilih untuk membeli obat analgesik eksternal di toko juga membeli obat di apotek.

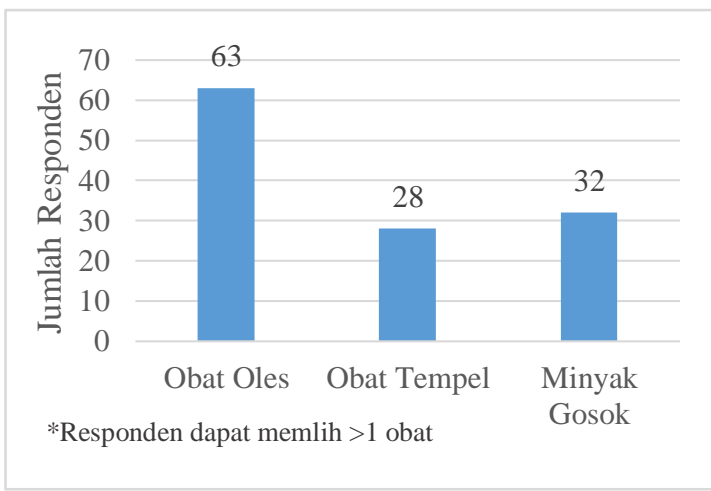

Gambar 5. Pilihan jenis obat yang digunakan oleh kuli angkut di PGS

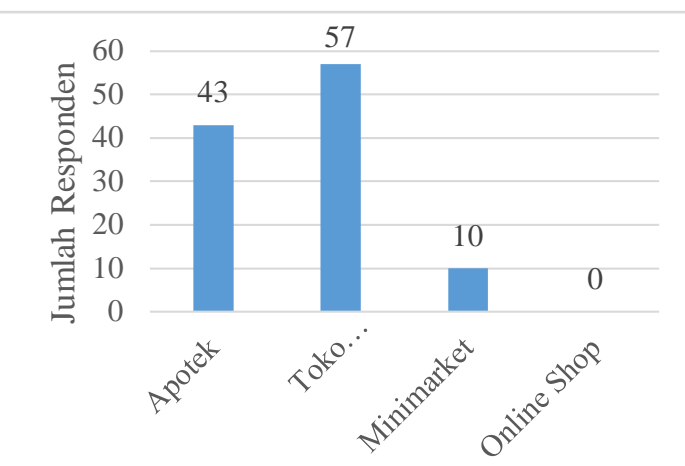

*Responden dapat memlih $>1$ obat

Gambar 6. Tempat kuli angkut PGS membeli obat

\section{Alasan Pemilihan Analgesik Eksternal}

Khasiat menjadi alasan kebanyakan responden memilih analgesik eksternal.

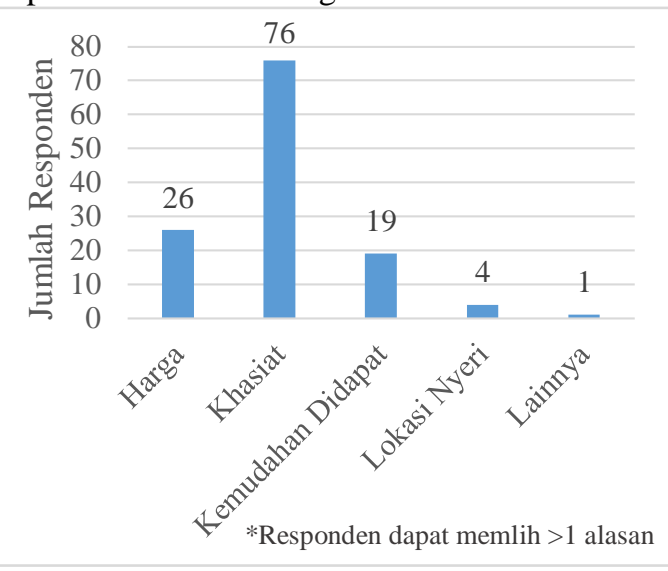

Gambar 7. Alasan kuli angkut PGS dalam memilih analgesik eksternal

Produk analgesik eksternal dapat menimbulkan khasiat dengan menimbulkan efek salah satunya dengan counterirritant. Counterirritant memiliki 
mekanisme kerja dengan menghasilkan vasodilatasi lokal, memberikan sensasi hangat pada kulit, memberikan efek analgesik dengan menutupi rasa/nyeri.

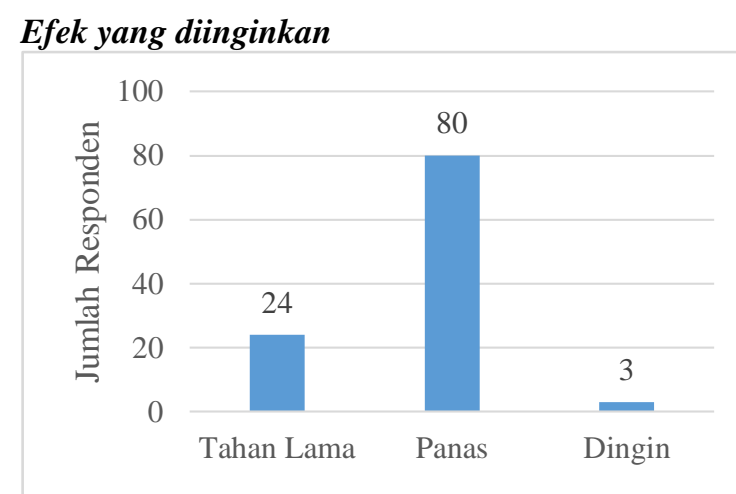

*Responden dapat memlih $>1$ efek

Gambar 8. Efek analgesik eksternal

Efek yang paling diinginkan oleh responden adalah efek panas. Hal ini menunjukkan bahwa produk-produk analgesik eksternal seperti balsam dan hot cream banyak disukai karena dalam penggunaannya akan menimbulkan efek panas.

\section{Penanganan Lanjutan Nyeri}

Berdasarkan survey yang kami lakukan, ada beberapa responden yang memutuskan untuk pergi ke dokter jika nyeri berlanjut dan hal ini merupakan langkah yang tepat. Namun, ada juga responden yang memutuskan untuk mengatasi nyeri berkelanjutan dengan istirahat, merendam bagian yang sakit dengan air hangat, mengganti obat, meminum jamu, dan memijat bagian yang sakit. Pijat atau massage memiliki variabilitas outcome berbeda yang kemungkinan terkait dengan variasi waktu pemijatan, dan metode pijat. Selain itu, tidak jelas apakah pijatan meningkatkan aliran darah lokal pada otot yang nyeri (Cheung ae al, 2003).

Delayed Onset Muscle Soreness (DOMS) biasanya terkait dengan kerja otot yang berat dan berulang. Istirahat merupakan solusi yang paling tepat dalam mengatasi DOMS. Stretching paling baik dilakukan sebelum melakukan pekerjaan berat untuk mencegah terjadinya nyeri otot karena stretching dapat merelaksasi otot (Cheung et al., 2003).

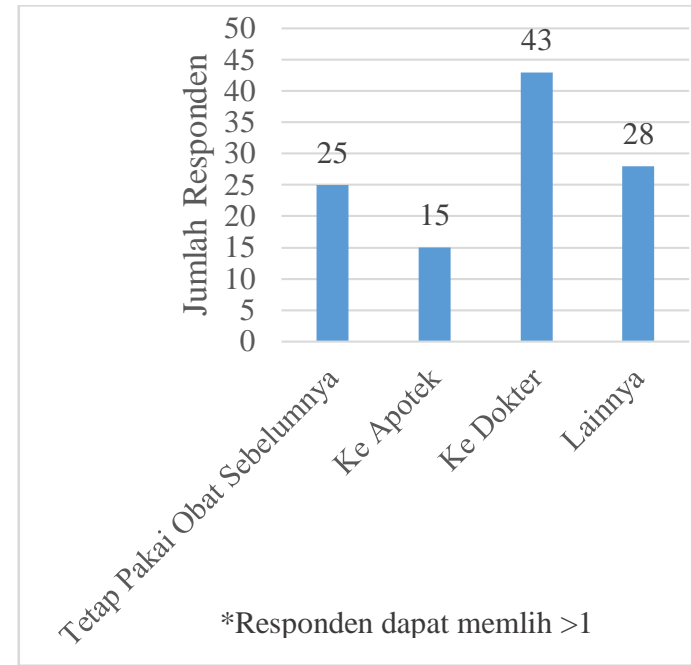

Gambar 9. Penanganan lanjutan nyeri

Berdasarkan data survei yang telah kami peroleh menunjukkan bahwa kuli angkut di Pusat Grosir Surabaya sangat jarang untuk pergi ke apotek dan berkonsultasi langsung dengan apoteker dalam memilih obat. Hal ini menunjukkan kurangnya sosialisasi mengenai peran apoteker sehingga kuli angkut PGS lebih sering membeli obat untuk mengatasi nyeri di toko kelontong..

\section{Pengetahuan Responden}

Pengetahuan dinilai berdasarkan jumlah benar dari 10 pernyataan yang kami berikan mengenai nyeri otot dan analgesik eksternal. Jawaban benar diberikan nilai 1, sedangkan jawaban salah diberi nilai 0 . Kemudian jawaban benar ditampilkan sebagai persentase nilai responden. Pengelompokkan pengetahuan responden berdasarkan kategori penilaian terlihat pada Tabel 2.

Tabel 2. Kategori penilaian pengetahuan responden

\begin{tabular}{cc}
\hline \hline Presentase & Kategori \\
\hline$<56 \%$ & Kurang \\
\hline $56 \%-75 \%$ & Cukup \\
\hline $76 \%-100 \%$ & Baik \\
\hline \hline
\end{tabular}

Tabel 3. Distribusi nilai pengetahuan responden

\begin{tabular}{cc}
\hline \hline Kategori & Presentase Responden \\
\hline Kurang & $44 \%$ \\
\hline Cukup & $43 \%$ \\
\hline Baik & $13 \%$ \\
\hline \hline
\end{tabular}


Tabel 4. Distribusi jawaban benar pada pertanyaan terkait pengetahuan responden

\begin{tabular}{lcc}
\hline \multicolumn{1}{c}{$\begin{array}{c}\text { Pengetahuan } \\
\text { Responden }\end{array}$} & $\begin{array}{c}\text { Persentase } \\
\text { jawaban } \\
\text { benar }(\%)\end{array}$ & $\begin{array}{c}\text { Kategori } \\
\text { Pengetahuan }\end{array}$ \\
\hline $\begin{array}{l}\text { Keamanan obat } \\
\text { di pedagang } \\
\text { kaki lima }\end{array}$ & $50 \%$ & Kurang \\
\hline $\begin{array}{l}\text { Tanggal } \\
\text { kadaluarsa obat }\end{array}$ & $87 \%$ & Baik \\
\hline $\begin{array}{l}\text { No. Registrasi } \\
\text { obat }\end{array}$ & $61 \%$ & Kurang \\
\hline $\begin{array}{l}\text { Indikasi } \\
\text { Efek Samping }\end{array}$ & $90 \%$ & Baik \\
\hline $\begin{array}{l}\text { Penggunaan } \\
\text { obat }\end{array}$ & $41 \%$ & Kurang \\
\hline $\begin{array}{l}\text { Penggunaan } \\
\text { analgesik } \\
\text { eksternal pada } \\
\text { luka terbuka }\end{array}$ & $80 \%$ & Baik \\
\hline $\begin{array}{l}\text { Pengobatan } \\
\text { nyeri }\end{array}$ & $26 \%$ & Kurang \\
\hline $\begin{array}{l}\text { Nyeri sebagai } \\
\text { awal timbulnya } \\
\text { penyakit }\end{array}$ & $72 \%$ & Cukup \\
\hline $\begin{array}{l}\text { Nyeri akibat } \\
\text { aktivitas berat } \\
\text { harus diobati }\end{array}$ & $18 \%$ & Kurang \\
\hline \hline
\end{tabular}

Mayoritas responden memiliki pengetahuan yang kurang mengenai analgesik ekternal dan penanganan nyeri seperti pada Tabel.3. Berdasarkan Tabel 4. Persentase hasil yang diperoleh, masih kurangnya pengetahuan responden mengenai penanganan nyeri akibat aktivitas berat, responden menganggap bahwa semua jenis nyeri harus diobati, padahal untuk nyeri karena olahraga yang berlebihan dapat sembuh hanya dengan istirahat cukup.

Rendahnya tingkat pengetahuan masyarakat mengenai penggunaan obat dinilai masih kurang. Hal ini akan berpengaruh dengan kesalahan pemilihan obat sehingga tujuan terapi tidak tercapai.

\section{KESIMPULAN}

Mayoritas kuli angkut di PGS mengatasi nyeri dengan obat analgesik eksternal jenis obat oles. Kuli angkut di PGS kurang memiliki pengetahuan mengenai obat analgesik eksternal. Kuli angkut di PGS banyak mendapatkan obat dari toko/warung sehingga paparan terhadap apoteker kurang. Kurangnya peran apoteker dalam pengatasan nyeri kuli angkut di PGS juga ditunjukkan oleh sedikitnya kuli angkut yang merujuk ke apotek saat nyeri berlanjut setelah penggunaan analgesik topikal di sinilah peran apoteker diperlukan.

\section{UCAPAN TERIMA KASIH}

Terima kasih kepada Ibu Mufarrihah, S.Si., M.Sc., Apt atas bimbingannya dalam menyusun manuskrip ini, Ibu Elida Zairina, S.Si., MPH, Ph.D., Apt. selaku PJMA dan Ibu Gesnita Nugraheni, S.Farm., M.Sc., Apt. selaku Koordinator Praktikum Farmasi Masyarakat serta Dekan Fakultas Farmasi Universitas Airlangga atas terselesaikannya kegiatan ini dengan baik.

\section{DAFTAR PUSTAKA}

Afif, A. 2015. Hubungan Tingkat Pengetahuan dengan Ketepatan Penggunaan Obat Analgetik pada Swamedikasi Nyeri di Masyarakat Kabupaten Demak. Naskah Publikasi; Fakultas Farmasi Universitas Muhammadiyah, Surakarta.

Ariens GAM, Bongers PM, Douwes M, Miedema MC, Hoogendoorn WE, Van der Wal G, et al. 2001. Are neck flexion, neck rotation, and sitting at work risk factors for neck pain? Results of a prospective cohort study. Occup Environ Med, 58: 200-7.

Bahrudin, M. 2018. Patofisiologi Nyeri (Pain). Jurnal Ilmu Kesehatan dan Kedokteran Keluarga; 13(1), 7.

Balai Kesehatan Tenaga Kerja Bogor. 2004. Penjaringan penyakit akibat kerja pada tenaga kerja pabrik pewarnaan benang di kabupaten bogor.

Subdirektorat Statistik Upah dan Pendapatan. 2019. Keadaan Pekerja di Indonesia Agustus 2019. Badan Pusat Statistika RI; 3-6. Jakarta: CV. Tanjung Citra.

Cheung, K., Hume, P. a, \& Maxwell, L. (2003). Treatment Strategies and Performance Factors. Sports Medicine, 33(2), 145-164. https://doi.org/10.2165/00007256-20033302000005

International Labour Organization. 2017. Laporan Ketanagakerjaan Indonesia 2017: Memanfaatkan Teknologi untuk Pertumbuhan dan Penciptaan Lapangan Kerja. ILO; 36. Jakarta: ILO.

Lee, J.-G., Kim, G. H., Jung, S. W., Kim, S. W., Lee, J.-H., \& Lee, K.-J. (2018). The association between long working hours and work-related musculoskeletal symptoms of Korean wage workers: data from the fourth Korean working conditions survey (a cross-sectional study). Annals of Occupational and Environmental Medicine, 30(1). doi:10.1186/s40557-018-0278-0 
Maskur, A., Della, H., dan Handini, F. 2013. Satuan Acara Penyuluhan Myalgia. Makalah; Program Studi Keperawatan Sekolah Tinggi Ilmu Kesehatan Budi Luhur, Cimahi.

Mickey S \& Patricia GB, 2007. Keperawatan Gerontik. EGC, Jakarta

Nathan, A. 2008. Managing Symptoms in the Pharmacy. Pharmaceutical Press; 125. Great Britain: TJ International, Padstow, Cornwall.

Sang, A., Djajakusli, R., dan Russeng, S. S. 2014. Hubungan Risiko Postur Kerja Dengan Keluhan Musculoskeletal Disorders (MSDs) Pada Pemanen Kelapa Sawit Di PT. Sinergi Perkebunan Nusantara. Repository UNHAS; 1-14.

Tanderi, A.T., Ajoe K., Hendrianingtyas, M.
2017. Hubungan Kemampuan Fungsional dan Derajat Nyeri pada Pasien Low Back Pain Mekanik di Instalasi Rehabilitasi Medik RSUP Dr. Kariadi Semarang. Jurnal Kedokteran Diponegoro, 6(1): 63-72.

Pemerintah Rapublik Indonesia 2003. Undang-undang Ketenagakerjaan Nomor 13 tahun 2003 tentang Ketenagakerjaan. Dilihat pada 19 November 2019

WHO. (2000). Guidelines for the regulatory assessment of medicinal products for use in self-medication. WHO Drug Information, Vol. 14, pp. 18-26. 